\title{
Digital age business model innovation for sustainability in University Industry Collaboration Model
}

\author{
Ari Happonen ${ }^{1 *}$, Ulla Santti $^{2}$, Harri Auvinen ${ }^{2}$, Teemu Räsänen ${ }^{3}$, and Tuomo Eskelinen ${ }^{2}$ \\ ${ }^{1}$ LUT School of Engineering Science, LUT University, Lappeenranta, 53850, Finland. \\ ${ }^{2}$ Bio- and Circular Economy, Savonia University of Applied Sciences, Kuopio, 70200, Finland. \\ ${ }^{3}$ Preventos Informatics, Kuopio, 70200, Finland.
}

\begin{abstract}
This study aims to investigate a digitalization-related business model as a result from the university-SME collaboration. The SME of the case study (Preventos Informatics Ltd) specializes in water distribution systems in industrial scale, telemetry, and sensor data-based monitoring of the water distribution-The business model of the company is a result of an innovation process during 2016-2017. The SME was established 2018. This study examines the commercialization process's success factors and compares the original business model to the finally implemented one after two years. The study reviews the current literature of sustainable business models and digitalization and reflects the results from this study. Based on the results, by quantifying the sustainability, environmental aspects and digitalization, value added can be brought to the business model. Our study suggests that by adding more digitalization, sensor technologies, and dataanalysis, quantifying the real value of innovations is possible.
\end{abstract}

\section{Introduction}

When collaborating for research, development, and innovation (RDI) and working together for a shared outcome, lot of skills, knowledge, and resources must be shared. Openly shared information can be seen as an accelerator for boosting and promoting novel innovations [1]. Depending on the partners, one of the major factors explaining the effectiveness of cooperation may be, in addition to skills and knowledge, the organizational culture, and how it is used to set up RDI cooperation [35]. As stated in [2], free resources, such as open data, drive the promise of public and private sector innovations. This promise could lead to, for example, the provision of open data to increase citizen engagement. As more open data becomes available, businesses and governments will have more information to access, which should improve decision-making and steer societal development debates in the needed directions. In addition, citizens' commitment can be used to harness the wisdom of the community as a tool for cooperation between municipalities to increase their resource efficiency and enable citizens to participate in the development of municipal activities [3]. As open data can be easily reused, the ingenuity and novelty are reached through the

\footnotetext{
*Corresponding author: ari.happonen@lut.fi
} 
integration into business models and the effective use of real-time open data in strategic decision-making.

This article focuses on the business model innovation for the digitalization of the water management sector. Here companies can provide integrated sensor data to build a new kind of competitive advantage, for example, as digital data managing services, or e.g., decisionmaking support tools for sustainability goals. In the university-industry collaboration context, collaborative innovation usually deals with a specific project with their named goals. The generic problem seems to be the lack of follow-up results [4], which can be partly explained by different operating cultures. On the other hand, if companies find their way to save time and manage the risk of collaborative resources and universities are allowed to do basic research on behalf of companies, a greater number of positive results can be expected [5]. In the field of sustainability-universities have an important role to play in cooperation [6], especially additional value of accessing to technological facilities, their social capital (usually also international view instead of local), student engagement, and sustainable-oriented values [7]. The next decade will have sustainability as centre development goals by the Horizon Europe, indicating clear financial benefits for all new sustainability promoting technologies. In future oriented universities the nature of collaboration is typically co-innovation. Start-ups in such work are expected to be agile, while higher education units and university researchers can leverage technological innovation, ideas, and strategies for entrepreneurs and investors to form a view on financing and the feasibility of commercialization [9].

In the context of sustainability research, one of the key roles of the Earth in sustaining life is water [10] and especially clean water as a condition of life for the planet [11]. That includes humankind making number of bad decisions in the past, which has led to pollution of some freshwater reserves and river flows [12]. Besides of quality of raw water sources, the aging infrastructure of urban water supply systems impairs water safety. On the other hand, the leaking pipes increase water distribution's energy use, having a major negative effect on overall sustainability. For reliable and efficient decision making in the future, the accurate data is needed $[13,14]$ to make existing problems and opportunities visible in correct scope and scale efficiently. For this specific data collection need, a business model for water monitoring services was created [15]. The idea was to start with a business idea, brainstorm items on the business model canvas, evaluate items in a multi-criteria evaluation based on feasibility, and finally select and design a business model. This service design and co-creation process has been reported in a previous study [15] as part of the Akseli project, which sought and tested new tools and approaches to accelerate business development through smart specialization water safety projects. This study seeks an answer to a research question in this follow-up publication: What were the essential additions to the collaborative sustainable development business model to achieve real implementation after university-industry collaboration?

Digitalization has reshaped the society with novel business models and technologies, but by current research, there is still lot to come from the SME sector [16]. E.g., in the industry side, with digitalization investments, many traditional businesses have transformed from tangible product developers to service businesses [17]. Also, decision-making is moving from asset level to fleet-level [18]. Development has been driven by the large-scale availability of a data, which has not been analysed for the decision-makers before. On the other hand, digitalization boosted the generation of open data and create opportunities for new innovations, specially e.g., for science [19], the public sector [20], and the developing countries [21].

In societies, things do not usually evolve by accident. Motivation and inspiration sources evolve by sustainability innovations, political guidelines, decisions, and restrictions, which are often behind the pressure towards new solutions. According to [23], decision-making in the public sector, related to the municipal area's infrastructure, is based on analysis of huge 
amounts of fragmented data, which does force municipalities to seek and utilize more efficient data analysis methods and simultaneously develop data collection, analysing and decision-making tools. For the public sector, trying alone to reach the UN Sustainable Development Goals (SDGs), will be huge undertaking, especially if the given deadline 2030 is the target. In Finland, to meet the given goals in time, the government has published a roadmap with SDGs in close collaboration with private, third and public sectors. The roadmap is a tool to help to go towards globally influencing sustainable financing ecosystem [24]. The mentioned steps are as follows: 1) investments in a sufficient number and quality, 2) convincing the management, 3) customization and identifying proper instruments, 4) influence reflected on SGDs 5) and proper knowledge and skills [25].

For example, according to City on Kuopio, in Finland, they see that evaluation of public decision-making effects has to be based on a pro-active approach. To achieve this, the city included environmental aspects under the ideology of "resource wise" in their strategy. This strategy includes topics like, logistics, circular economy, traffic, renewable energy \& energy efficiency, efficient water management and wise use of resources. Political decisions are often also boosting the product development and creates markets for environmentally friendly new technology [54].

\section{Method}

The studied business model was developed in a four-stage innovation process: 1) context definition, 2) idea generation, 3) determining the business model items through core indexing, and 4) defining the business model and re-designing due analysis of the evaluation information from multi-criteria decision support (MCDS) [15] [38]. The current study compares the 2017 collaboratively designed business model to 2020 implemented version. Many researchers consider business models as slowly constructing iterative processes [42]. Also, researchers agree on a research gap in business model creation and practice-based understanding business model processes [42, 43, 44, 45, 46, 47].

Considering collaborative sustainability, Although consumers are knowledgeable and concerned about global warming and the environment [26], multiple aspects are supporting sustainable purchasing, there are also barriers e.g., in environmental-friendly food shopping: knowledge and marketing do not leads only to good intentions but not into actual purchasing actions, consumers make wrong conclusions, prefer other qualities as more important or they have a lack of awareness, credibility and/or motivation for sustainable purchases [27]. Also, consumer's opinions are polarized towards environmental-friendliness and low price is often competing against sustainability [28]. Sometimes consumers need to be encouraged towards sustainable behaviour, e.g. by digitalization and gamification [29].

The water resources on Earth are stressed by the population and the socio-economic development [30]. Also, the covid-19 pandemic led into decreasing in global markets, although major markets improve somewhat quickly towards normal [30], the unfortunate influences are that companies are postponing their sustainable development activities. Business model development plays a crucial role in survival in changing market conditions [31]. From the real problem setting, the new business model's idea was to secure the domestic water for future generations, based on real real-time data describing the functioning of water distribution. For example, pressure bursts in aging infrastructure (pipes, pumps, valves) cause leaks in distribution network leading to waste of clean water and reducing water safety. Thus, there is a growing need for smart water management to improve predictive control of water distribution, to increase water safety and optimize the efficient use of clean water in general. According to [32], water distribution losses are circa $48 \%$ in Ireland, $23 \%$ in Finland, and $41 \%$ in Romania. The business model responds to this need with a real-time monitoring system for water management to automatically detect and locate abnormal situations as 
leakages and pressure bursts with modern IoT technology [33]. The crucial question from the business side is, what are the needed benefits, for the customer to be ready to pay for this sort of sustainability boosting solution?

\subsection{Data collection and analysis}

The business model process (Fig 1.) includes 5 phases: 1. Design of context (setting of goals plus identification of participants and their roles for the process), 2. Idea generation, 3. Evaluation of Ideas, 4. Core Value calculation, 5. Deployment to achieve value $[15,38]$. Instead of building typical nine blocks in a business model canvas, BM consists of 12 building blocks, which are chosen with a portfolio decision analysis (PDA) and multi-criteria decision support (MCDS) [8]. Successful context definition, identification of participants, and goal setting are needed in business model creation.

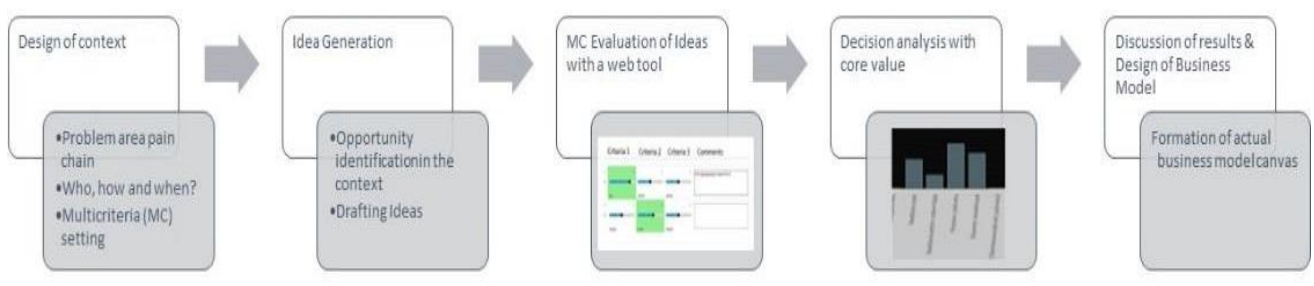

Fig. 1. MCDS business model process (visualising model based on $[15,38]$ )

Based on 2017 developed business model, the Preventos Informatics Ltd. was founded on 2018 with few part-time personnel and first year turnover circa 33,000 €. In March 2019, the full-time operations started, yearly turnover raised to $58,000 €$, and services were further developed in cooperation with existing customers, and also new customer relationships were in the mining and water utilities sectors. The updated business model with comparison to the 2017 model is presented in Figure 2.

2017 to 2020 Preventos Ltd. Business Model develpoment analysed in Model Canvas Format

\begin{tabular}{|c|c|c|c|c|}
\hline \multicolumn{5}{|c|}{$\begin{array}{l}\text { Customer Need } \\
\text { Ready and easy to use, customized product. Automization of data analysis, predictive information. } \\
\text { Smart water management to improve control, water use efficiency and water safety. Small water utilities have lack of resources, ICT skills and technical support. Ready and easy to use information services. } \\
\text { Customized product for water management. Automatization of data analysis, information for predictive maintenance. }\end{array}$} \\
\hline \multicolumn{2}{|c|}{$\begin{array}{l}\text { Company Solutions } \\
\text { Fullservice packagefeforcompanyneedsereporting Services. ICT service: } \\
\text { monitoring water distribution, wireless data transfer and data analysis. }\end{array}$} & \multicolumn{3}{|c|}{$\begin{array}{l}\text { Competing Solutions } \\
\text { Commercial information systems. Not many dedicated for water management. }\end{array}$} \\
\hline $\begin{array}{l}\text { Key Partners } \\
\text { Metere and sensor manufucturers, } \\
\text { authorities, ICT automation systems } \\
\text { Wireless lơ data logger }\end{array}$ & $\begin{array}{l}\text { Value Proposition } \\
\text { Easa to use, scining time, usefulinformation } \\
\text { availabibe, Accurate long lasting wireless } \\
\text { measurements, situational awareness }\end{array}$ & $\begin{array}{l}\text { Key Tasks } \\
\text { Ensure supply chain monitoring \& } \\
\text { operational stability, guaranteeing } \\
\text { continuity. }\end{array}$ & $\begin{array}{l}\text { Customer Relationships } \\
\text { Refined measuring data, long-term } \\
\text { customer relationships }\end{array}$ & 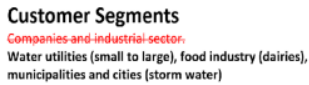 \\
\hline \multicolumn{3}{|c|}{$\begin{array}{l}\text { Key Resources } \\
\text { Service providers (sotware, knowledge transfer \& accounting, field experts, environmental measurements \& data production) }\end{array}$} & \multicolumn{2}{|c|}{$\begin{array}{l}\text { Channels } \\
\text { Internet, direct contacts, senser supplief, social media }\end{array}$} \\
\hline \multicolumn{2}{|c|}{$\begin{array}{l}\text { Cost Structure } \\
\text { Sensors, wireless statat logeres, cloud-based iCT system development, system }\end{array}$} & \multicolumn{3}{|c|}{$\begin{array}{l}\text { Cash Flow } \\
\text { Improver risk management, preventing and mini mizing (environmental) damages. }\end{array}$} \\
\hline
\end{tabular}

Fig 2. Extended Business Model Canvas comparison of 2017 designed BM and 2020 actual BM.

The CEO of Preventos Informatics Ltd. and participating researchers from the initial RDI process were interviewed to gather data about the comparison of 2017 with MCDS tools developed business model and actual 2020 existing business model. In the original canvas, the criteria for evaluating ideas (Fig. 1) in the business model process were business potential, customer need/benefit, and results were collected into extended business model canvas $[15$, 
48]. These criteria's turned out to be chosen wisely by the business model process participants, because no much has changed from 2017, but some building blocks have been iteratively developed serving customer needs even better than in original plan (Figure 2).

When considering market potential, water rehabilitation needs in Finland are 320 million euros in the next 15-20 years. There are 1,500 water utilities in Finland of which municipalities own 400 of them and 1,100 are privately owned small water utilities. Many industries are dependent of water and there are 50 dairies, and in Europe there are 120,000 dairy refineries. Global water markets are growing also alongside of IoT industry, e.g., in US on 2019 the water market size was $\$ 7.14$ billion, and it is estimated on 2025 the US market will be $\$ 13.81$ billion [49].

\section{Results and discussion}

Preventos Informatics Ltd CEO Teemu Räsänen analyzed differences between the business models. These differences were found to be a practical cause of follow-up work focusing mostly into deeper analysis of customer needs, purchasing behavior, and other customers' purchasing decisions (Table 1). Also, the target segment classification work was seen as an important matter, because-each segment has specific needs, marketing strategy-approaches, and decision-making strategies. The decision-making strategies were dependent to the customer type because it can be a company, municipal institution, or water cooperative.

Table 1. Comparison of 2017 designed and 2020 implemented business models.

\begin{tabular}{|l|l|}
\hline BMC Building Block & Analysis of Differences Between 2017 and 2020 \\
\hline Customer Need & $\begin{array}{l}2020 \text { more details: improved water management control, resources, ICT } \\
\text { skills, automatization, predictive analysis }\end{array}$ \\
\hline Company Solution & same principles, 2020 more details. Added: data analysis. \\
\hline Competing Solution & same than 2017 \\
\hline Key Partners & same than 2017 \\
\hline Value Proposition & $\begin{array}{l}\text { same principles, 2020 more details. Added: accurate, long lasting wireless } \\
\text { measurements and situational awareness }\end{array}$ \\
\hline Key Tasks & same than 2017 \\
\hline Customer Relationships & same than 2017 \\
\hline Customer Segments & $\begin{array}{l}\text { a lot more detailed information 2020: water utilities and food industry. } \\
\text { Added: municipalities and cities management. }\end{array}$ \\
\hline Key Resources & same than 2017 \\
\hline Channels & $\begin{array}{l}\text { Same: internet and direct contacts. Did not happen: sensor suppliers. More } \\
\text { specified: social media }\end{array}$ \\
\hline Cost Structure & same principles, 2020 more details. Added: marketing and sales costs. \\
\hline Cash Flow & $\begin{array}{l}\text { Same: improved risk management \& damage prevention. Not: } \\
\text { environmental. Added: planning of water network rehabilitation, improved } \\
\text { water safety }\end{array}$ \\
\hline
\end{tabular}




\section{Conclusion}

Digitalization, IoT and platform solutions are currently one of the biggest new business model generators, crosscutting all business sectors. Preventos Informatics Ltd. digital water monitoring services were developed according to design thinking method which offers novel approaches into the problem solving and radical innovation development, but the actual strength is the human approach and in this case customer-oriented approach. In this case, according to Preventos CEO, the strength of the collaboration process with higher education unit was specifically the structure to include many potential customers representing, from many different target segments in workshops, which helped analysing their own needs for water monitoring services and by doing so generated the good seeds for continuation of innovation work. The largest customers and stakeholders were present and came to workshops from municipal waterworks facilities, mining sector, and private small water facilities and different officials to give wider perspective of customer needs at once. Participants had deep knowledge of what they would need in the future and used it to participate in idea evaluation according to InTo process. The CEO pinpointed to prefer to see potential financing bodies into workshops to get the financing feasibility view as part of new business collaborative development workshops.

Considering the experiences from water supply experts' point of view, the first priority seemed to exist in providing more decision-making information and the quality of the information produced to meet user needs for this business model development efforts. Therefore, in practice, it is important that the service can meet the right need and bring cost savings and, for example, increase water safety through, for example, preventive maintenance. For example, Preventos Informatics Ltd. provide service to detects possible leaks automatically in the water distribution system. The algorithm analyses the sensor measurements online and detects an anomalous situation, then generates alarms and visual graphical data to web user interface in order to give instantaneous information about the problem and it's location. Things that could indicate problem can be e.g., a detected pressure shock, caused by a momentary shutdown of the pump, which was a cause from a power failure. In active alarm mode, an alarm generates SMS message to key person(s) mobile phone and email alert notification is also dispatched to inform maintenance staff of the deviation in water distribution.

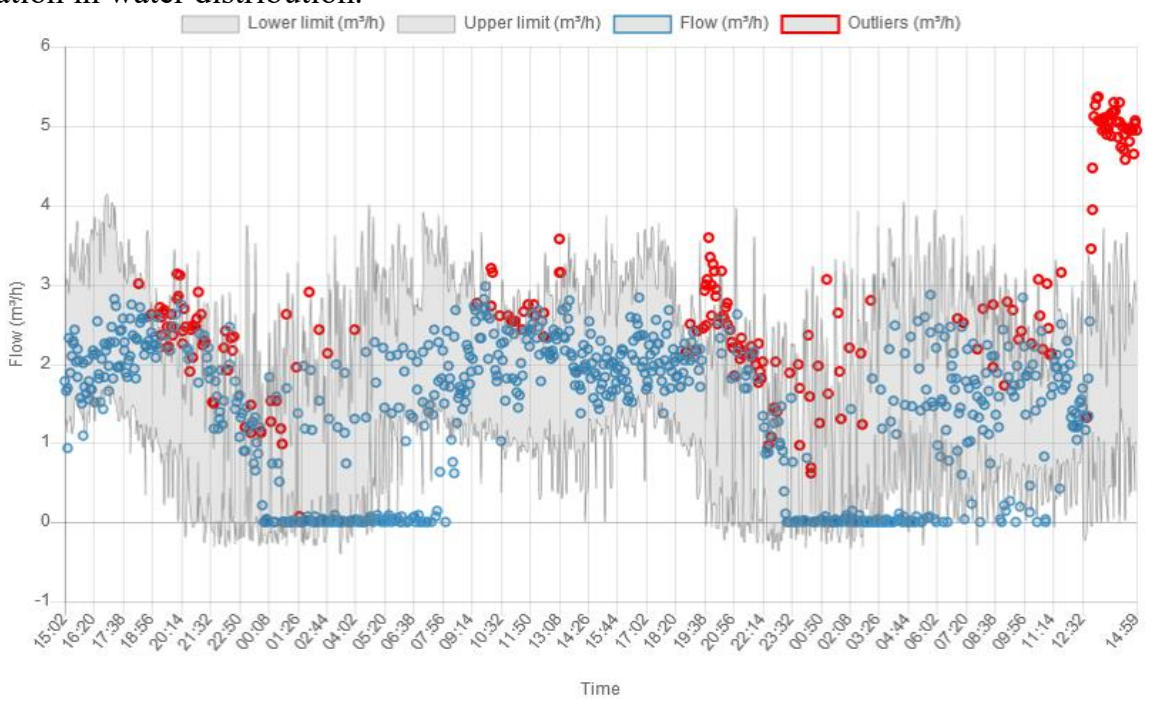

Fig. 3. Time series data from real-time monitoring system pinpointing the abnormal situations. 
For customer usability, visualization has an important role in analyzing the causes for the interferences, comparing data within different time periods, and transforming data into information and knowledge (Figure 3). Basically, visualization will make things more understandable, and visual images are also lot easier for people to remember and share information to larger audiences.

Preventos customer promise is in addition to cost savings, to provide reliability and the ability to react more quickly to faults so that they are detected more quickly. Informative map application points out leakages to certain locations and makes it easier for maintenance staff to navigate immediately to the right spot. This is usually possible only with expensive software's from large operators, but Preventos has commercialized map application with integration of traffic light system for small water utilities as well with lower priced solution (Figure 4).

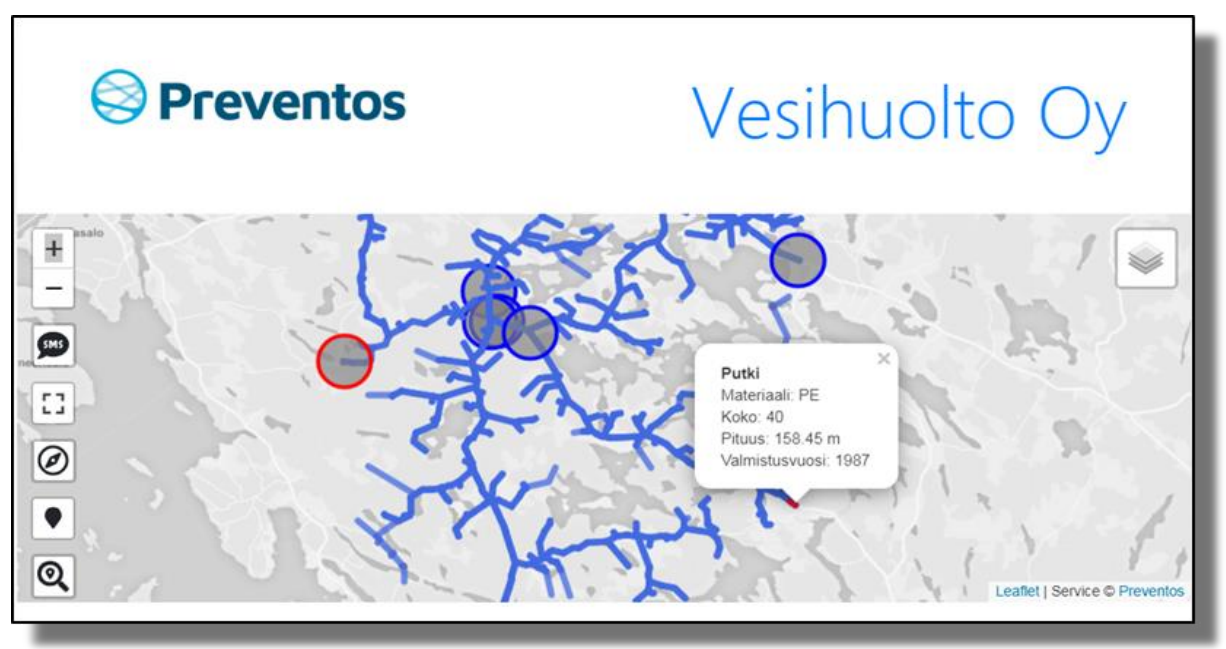

Fig. 4. Water supply infrastructure related information presented on the map as spatial information.

Considering the findings, research can e.g., offer new know-how for digital design process tools and support mass customization considerations; companies might have with the newest business models [50, 51]. And considering the newest technologies, also innovation seeding options like collaborative hackathons [34, 36, 43], capstone courses [39] and digital citizen science solutions [55] should be given a tough, as these methods have also shown productivity [40] sustainability context. The research can also push newest technologies like Artificial Intelligence [52, 53] and industry 4.0 technologies [22] to forms that help companies produce new circularity and sustainability enhancing products and services. All in all, as SME resources are typically tight, emphasis could be put to the fuzzy front end [37] towards novel innovations to proceed towards efficient, win-win based and trust driven innovations [41].

\section{Acknowledgements}

This research is contributing to AWARE project, funded by The South-East Finland - Russia CBC 2014-2020 cross-border cooperation programme. The programme is funded by the European Union, the Russian Federation and the Republic of Finland. Authors would like to express their gratitude for CBC 2014-2020 cross-border cooperation programme providing the possibility to focus on sustainability enhancing business model, contributing educational knowledge generation. 


\section{References}

1. A. Zuiderwijk, N. Helbig, R. Gil-García, M. Janssen, Special Issue on Innovation through Open Data - A Review of the State-of-the-Art and an Emerging Research Agenda: Guest Editors' Introduction, J. theor. appl. electron. commer. res., 9, 2 (2014), p. I-XIII, https://doi.org/10.4067/S0718-18762014000200001

2. A. Luthfi, M. Janssen, Open Data for Evidence-based Decision-making: Data-driven Government Resulting in Uncertainty and Polarization, IJASEIT, 9, 3 (2019), pp. 1071-1078

3. V. Palacin, S. Ginnane, M.A. Ferrario, A. Happonen, A. Wolff, S. Piutunen, N. Kupiainen, SENSEI: Harnessing Community Wisdom for Local Environmental Monitoring in Finland, CHI Conference on Human Factors in Computing Systems, Glagsgow, Scotland UK, (2019), pp. 1-8, https://doi.org/10.1145/3290607.3299047

4. F. Findler, N. Schönherr, R. Lozano, D. Reider, A. Martinuzzi, The impacts of higher education institutions on sustainable development, Int. J. Sustain. High. Educ., 20, 1 (2019), pp. 23-38, https://doi.org/10.1108/IJSHE-07-2017-0114

5. M. Hirvimäki, M. Manninen, A. Lehti, A. Happonen, A. Salminen, O. Nyrhilä, Evaluation of Different Monitoring Methods of Laser Additive Manufacturing of Stainless Steel, Advanced Materials Research, 651, (2013), pp. 812-819, https://doi.org/10.4028/www.scientific.net/AMR.651.812

6. J. Youtie, P. Shapira, Building an innovation hub: A case study of the transformation of university roles in regional technological and economic development, Research policy, 37, 8 (2018), pp. 1188-1204

7. F. Monavvarifard, M. Baradaran, B. Khosravipour, Increasing the sustainability level in agriculture and Natural Resources Universities of Iran through students' engagement in the value Co-creation process, J. Clean. Prod, 234, (2019), pp. 353-365

8. J. Liesiö, P. Mild, A. Salo, Preference Programming for Robust Portfolio Modeling and Project Selection, European Journal of Operational Research, 181, 3 (2007), pp. 14881505, https://doi.org/10.1016/j.ejor.2005.12.041

9. R. Rybnicek, R. Königsgruber, What makes industry-university collaboration succeed? A systematic review of the literature, J. Bus. Econ, 89, (2019). pp. 221-250

10. M.F. Chaplin, Water: its importance to life, Biochemistry and Molecular Biology Education, 29, 2 (2001), pp. 54-59, https://doi.org/10.1111/j.15393429.2001.tb00070.x

11. P. Levallois, C.M. Villanueva, Drinking Water Quality and Human Health: An Editorial, Int. J. Environ. Res. Public Health, 16, 4 (2019), pp. 1-4

12. S. Sabater, F. Bregoli, V. Acuña, D. Barceló, A. Elosegi, A. Ginebreda, R. Marcé, I. Muñoz, L. Sabater-Liesa, V. Ferreira, Effects of human-driven water stress on river ecosystems: a meta-analysis, Scientific Reports, 8, (2018), pp. 1-11

13. O.A. Alshikhi, B.A. Abdullah, Information Quality: Definitions, Measurement, Dimensions, and Relationship with Decision Making, EJBIR, 6, 5 (2018), pp. 36-42

14. Z. Houhamdi, B. Athamena, Impacts of information quality on decision-making, GBER, 21, 1 (2019), pp. 26-42

15. T. Eskelinen, T. Räsänen, U. Santti, A. Happonen, M. Kajanus, Designing a Business Model for Environmental Monitoring Services Using Fast MCDS Innovation Support Tools. TIM Review, 7, 11 (2017), pp. 36-46, http://doi.org/10.22215/timreview/1119 
16. P. De Bernardi, A. Bertello, F. Ricciardi, S. Moggi, Business Model Innovation in SMEs Engagin in Innovation Ecosystems: a Decoupling Perspective, In ITAIS and MCIS 2019: a Joint Conference Event, (2019), pp. 1-10

17. H. Kortelainen, A. Happonen, J. Hanski, From asset provider to knowledge company transformation in the digital era, In Lecture Notes in Mechanical Engineering, (2019), pp. 333-341, https://doi.org/10.1007/978-3-319-95711-1_33

18. H. Kortelainen, A. Happonen, S-K. Kinnunen, S-K., Fleet Service GenerationChallenges in Corporate Asset Management", Lecture Notes in Mechanical Engineering, pp. 373-380, (2016), https://doi.org/10.1007/978-3-319-27064-7 35

19. J.C. Molloy, The Open Knowledge Foundation: Open Data Means Better Science, PLoS Biology, 9, 12 (2011), e1001195, https://doi.org/10.1371/journal.pbio.1001195

20. P. Huston, V.L. Edge, E. Bernier, Reaping the benefits of Open Data in public health, Canada Communicable Disease Report, 45, 11 (2019), pp. 252-256

21. S. Verhulst, A. Young, Open Data in Developing Economies: Toward Building an Evidence Base on What Works and How, ISBN: 978-1-928331-59-9, (2017), p. 281

22. M. Ghoreishi, A. Happonen, M. Pynnönen, Exploring Industry 4.0 Technologies to Enhance Circularity in Textile Industry: Role of Internet of Things, In Twenty-first International Working Seminar on Production Economics, February 24-28, 2020, Innsbruck, Austria, p. 16

23. H. Auvinen, U. Santti, A. Happonen, Technologies for Reducing Emissions and Costs in Combined Heat and Power Production, E3S Web Conf., 158, (2020), pp. 1-6, https://doi.org/10.1051/e3sconf/202015803006

24. Finnish Government: Ministry of Agriculture and Forestry, 2019, Private capital to help solve global challenges, https://valtioneuvosto.fi/en/article/-

/asset_publisher/1410837/yksityinen-paaoma-globaalien-ongelmien-ratkaisijaksi

25. Gaia Consulting Oy, SDGs roadmap to sustainable investments, https://kestavakehitys.fi/ajankohtaista/artikkeli//asset_publisher/1410837/hyvinvointia-yhteiskunnalle-ja-tuottoa-sijoittajalle (2019)

26. W. Young, K. Hwang, S. McDonald, C.J. Oates, Sustainable consumption: green consumer behaviour when purchasing products. Sustainable development, 18, 1 (2010), pp. 20-31.

27. K.G. Grunert, Sustainability in the food sector: A consumer behaviour perspective, International Journal on Food System Dynamics, 2, 3 (2011), pp. 207-218

28. G. Antonides, Sustainable consumer behaviour: A collection of empirical studies, Sustainability, 9, 10 (2017), Article: 1686, https://doi.org/10.3390/su9101686

29. U. Santti, A. Happonen, H. Auvinen, Digitalization Boosted Recycling: Gamification as an Inspiration for Young Adults to do Enhanced Waste Sorting, AIP Conference Proceedings, 2233, 1 (2020), pp. 1-12, https://doi.org/10.1063/5.0001547

30. Y. Shen, T. Oki, S. Kanae, N. Hanasaki, N. Utsumi, M. Kiguchi, Projection of future world water resources under SRES scenarios: an integrated assessment, Hydrological Sciences Journal, 59, 10 (2014), pp. 1775-1793

31. S. Kraus, T. Clauss, M. Breier, J. Gast, A. Zardini, V. Tiberius, The economics of COVID-19: initial empirical evidence on how family firms in five European countries cope with the corona crisis, Int. J. Entrepreneurial Behav. Res., 26, 5 (2020), pp. 1067 1092, https://doi.org/10.1108/IJEBR-04-2020-0214 
32. B. Tisserand, Europe's water in figures, The European Federation of National Associations of Water Services, (2017), http://www.eureau.org/resources/publications/1460-eureau-data-report-2017-1/file

33. Interneg, EU Digital Resources. 2017. https://www.interregcentral.eu/Content.Node/Digital-Learning-Resources/03-Water-Loss.pdf

34. J. Porras, J. Khakurel, J. Ikonen, A. Happonen, A. Knutas, A. Herala, O. Drögehorn, Hackathons in software engineering education - lessons learned from a decade of events, International Conference on Software Engineering 2018 (ICSE), Gothenburg, Sweden, (2018), pp. 40-47, https://doi.org/10.1145/3194779.3194783

35. U. Santti, T. Eskelinen, M. Rajahonka, K. Villman, A. Happonen, Effects of Business Model Development Projects on Organizational Culture: A Multiple Case Study of SMEs, TIM Review, 7, 8 (2017), pp. 15-26, http://doi.org/10.22215/timreview/1096

36. J. Porras, A. Knutas, J. Ikonen, A. Happonen, J. Khakurel, A. Herala, Code camps and hackathons in education - literature review and lessons learned, HICSS 2019, Hawaii, USA, pp. 7750-7759, (2019), https://doi.org/10.24251/hicss.2019.933

37. E. Salmela, C. Santos, A. Happonen, Formalization of Front End Innovation in Supply Network Collaboration, IJIRD, 5, 1 (2013), pp. 91-111, https://doi.org/10.1504/IJIRD.2013.052510

38. M. Kajanus, A. Iire, T. Eskelinen, M. Heinonen, E. Hansen, Business Model Design: New Tools for Business Systems Innovation, Scandinavian Journal of Forest Research, 29, 6 (2014), pp. 603-614, https://doi.org/10.1080/02827581.2014.949301

39. M. Palacin-Silva, J. Khakurel, A. Happonen, T. Hynninen, J. Porras, Infusing Design Thinking Into a Software Engineering Capstone Course, The 30th IEEE CSEE\&T, Savannah, Georgia, USA, (2017), pp. 1-10, http://dx.doi.org/10.1109/CSEET.2017.41

40. A. Happonen, D. Minashkina, A. Nolte, M.A. Medina Angarita, Hackathons as a Company - University Collaboration Tool to Boost Circularity Innovations and Digitalization Enhanced Sustainability, AIP Conference Proceedings, 2233, 1 (2020), pp. 1-11, https://doi.org/10.1063/5.0001883

41. A. Happonen, V. Siljander, Gainsharing in Logistics Outsourcing: Trust leads to Success in the Digital Era, International Journal of Collaborative Enterprise, 6, 2 (2020), pp. 150-175, https://doi.org/10.1504/IJCENT.2020.110221

42. M. Sosna, R.N. Trevinyo-Rodríguez, S.R. Velamuri, Business Model Innovation through Trial-and-Error Learning, Long Range Planning, 43, 2-3 (2010), pp. 383-407, https://doi.org/10.1016/j.lrp.2010.02.003

43. A. Happonen, D. Minashkina, Ideas and experiences from university industry collaboration: Hackathons, Code Camps and citizen participation, LUT Reports series report 86, ISBN: 978-952-335-253-7, ISSN: 2243-3384, pp. 1-21, (2018), https://doi.org/10.13140/rg.2.2.29690.44480

44. H. Chesbrough, Business model innovation: opportunities and barriers, Long Range Planning, 43, 2-3 (2010), pp. 354-363, https://doi.org/10.1016/j.lrp.2009.07.010

45. R.G. McGrath, Business models: A discovery driven approach, Long Range Planning, 43, 2-3 (2010), pp. 247-261, https://doi.org/10.1016/j.lrp.2009.07.005

46. A. Osterwalder, Y. Pigneur, Business Model Generation. John Wiley and Sons: New Jersey, (2010).

47. P. Ahokangas, J. Myllykoski, The Practice of Creating and Transforming a Business Model, JOBM, 2 , 1 (2014), pp. 6-18, https://doi.org/10.5278/ojs.jbm.v2i1.719 
48. A. Osterwalder, Y. Pigneur, C.L. Tucci, Clarifying business models: Origins, present, and future of the concept, Communications of the association for Information Systems, 16, 1 (2005), https://doi.org/10.17705/1CAIS.01601

49. Mordor Intelligence Report. 2019. https://mordorintelligence.com/industryreports/smart-water-management-market

50. H. Piili, T. Widmaier, A. Happonen, J. Juhanko, A. Salminen, P. Kuosmanen, O. Nyrhilä, Digital design process and additive manufacturing of a configurable product, Journal Advanced Science Letters, 19, 3 (2013), p. 926-931, https://doi.org/10.1166/asl.2013.4827

51. T. Widmaier, J. Juhanko, H. Piili, P. Kuosmanen, A. Salminen, A. Happonen, J. Kontio, O. Nyrhilä, Digital design and manufacturing process comparison for new custom made product family - a case study of a bathroom faucet, Estonian Journal of Engineering, 19, 1 (2013) pp. 76-89, http://dx.doi.org/10.3176/eng.2013.1.07

52. M. Ghoreishi, A. Happonen, Key enablers for deploying artificial intelligence for circular economy embracing sustainable product design: Three case studies, AIP Conference Proceedings, 2233, 1 (2020), pp. 1-19, https://doi.org/10.1063/5.0001339

53. M. Ghoreishi, A. Happonen, New promises AI brings into circular economy accelerated product design: a review on supporting literature, E3S Web Conf., 158, pp. 1-10, https://doi.org/10.1051/e3sconf/202015806002

54. J. Meadowcroft, What about the politics? Sustainable development, transition management, and long term energy transitions, Policy sciences, 42, 4 (2019), pp. 323 340

55. V. Palacin, S. Gilbert, S. Orchard, A. Eaton, M.A. Ferrario, A. Happonen, Drivers of Participation in Digital Citizen Science: Case Studies on Järviwiki and Safecast, Citizen Science: Theory and Practice, 5, 1 (2020) pp. 1-20, http://doi.org/10.5334/cstp.290 